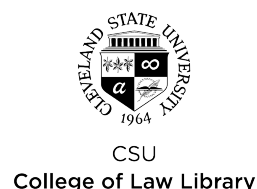

The Global Business Law Review

Volume 1 | Issue 2

Article

2011

\title{
Transnational Securities Fraud and the Extraterritorial Application of U.S. Securities Laws: Challenges and Opportunities
}

Genevieve Beyea

Texas Tech University School of Law

Follow this and additional works at: https://engagedscholarship.csuohio.edu/gblr

Part of the International Trade Law Commons, and the Securities Law Commons

How does access to this work benefit you? Let us know!

\section{Recommended Citation}

Genevieve Beyea, Transnational Securities Fraud and the Extraterritorial Application of U.S. Securities Laws: Challenges and Opportunities, 1 Global Bus. L. Rev. 139 (2010-2011)

This Article is brought to you for free and open access by the Journals at EngagedScholarship@CSU. It has been accepted for inclusion in The Global Business Law Review by an authorized editor of EngagedScholarship@CSU. For more information, please contact library.es@csuohio.edu. 


\title{
TRANSNATIONAL SECURITIES FRAUD AND THE EXTRATERRITORIAL APPLICATION OF U.S. SECURITIES LAWS: CHALLENGES AND OPPORTUNITIES
}

\author{
GENEVIEVE BEYEA*

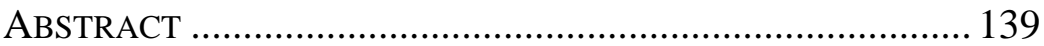

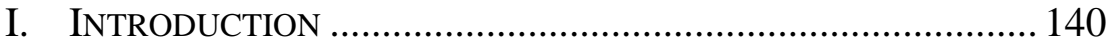 \\ II. The SECURItIES ANTIFRAUd RULES AND THE GLOBAL \\ ECONOMY .................................................................... 141 \\ A. Rule 10b-5: The Catch-All Antifraud Provision.......... 142 \\ B. Lawsuits Under the Antifraud Rules and \\ "Foreign-Cubed" Cases. \\ 143 \\ III. EXTRATERRITORIAL APPLICATION OF THE U.S. SECURITIES \\ ANTIFRAUD RULES ......................................................... 145 \\ A. The Restatement (Third) of Foreign Relations Law .... 145 \\ B. The Conduct and Effects Tests................................. 147 \\ C. A Procedural Note .................................................... 148 \\ IV. The CONDUCt Test In Focus: ForeIgn-Cubed CASES \\ AND THE PROBLEMS OF UNDER AND OVERREGULATION...... 150 \\ A. Morrison v. National Australia Bank ......................... 150 \\ B. The Problems of Under and Overregulation ................ 153 \\ V. StRiKing The Right BALANCE: PROSPECTS AND \\ OPPORTUNITIES FOR REFORM ............................................. 156 \\ A. A Market-Based Approach? ...................................... 157 \\ B. The Case for a Multilateral Resolution ...................... 160

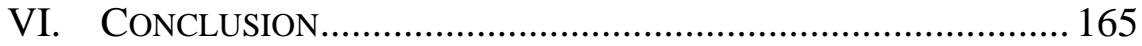

\begin{abstract}
With globalization, securities markets have become increasingly interconnected, and securities fraud has frequently crossed borders, creating problems for national regulators seeking to deter and punish fraud. The United States' well-developed private enforcement mechanism for securities fraud is very attractive to investors around the world who are harmed by transnational securities fraud, particularly those from countries where private enforcement mechanisms do not exist or fraud is under-regulated. The application of U.S. securities law to foreign investors,

\footnotetext{
* Assistant Professor, Texas Tech University School of Law; J.D., New York University School of Law; B.A., Northwestern University.
} 
however, presents a number of challenges, creating the potential for both under and overregulation as well as possible conflict with the regulatory systems of other jurisdictions. This Article outlines the current law on extraterritorial application of the securities antifraud rules, including a number of important recent developments in the case law. It examines the challenges presented by the increasing globalization of financial markets, and provides a fresh perspective in the debate on the proper scope of the extraterritorial application of U.S. securities law. Ultimately, this aticle argues against further judicial limitations on the extraterritorial application of the securities laws, but urges the development of a multilateral agreement to address the numerous and significant challenges presented by transnational securities fraud.

\section{INTRODUCTION}

With globalization, securities markets have become progressively more interconnected, and securities fraud has increasingly crossed borders, creating problems for national regulators seeking to deter and punish fraud. The United States' well-developed private enforcement mechanism for securities fraud is very attractive to investors around the world who are harmed by transnational securities fraud, particularly those from countries where private enforcement mechanisms do not exist or fraud is under-regulated. ${ }^{1}$ The application of U.S. securities law to foreign investors, however, challenges traditional presumptions against extraterritorial application of the law. Furthermore, broad extraterritorial assertions of U.S. antifraud rules can have a negative effect on business interests, and can lead to jurisdictional conflict with other countries. ${ }^{2}$ Courts hearing claims brought by foreign investors under U.S. antifraud rules must balance these considerations against the aims of deterring securities fraud and protecting U.S. markets and investors. Given the competing normative concerns and the increasingly complex fact patterns in transnational securities fraud cases, courts have struggled to delineate the proper scope of the extraterritorial application of the U.S. antifraud rules.

Recent events have shown that, if anything, more rather than less regulation of securities fraud is necessary. The private enforcement mechanism provided for by the securities antifraud rules is an important tool in deterring and punishing transnational securities fraud that has some connection to the United States. This aticle will argue in favor of a flexible approach to determining the extraterritorial application of the securities antifraud rules. However, recognizing the valid concerns regarding jurisdictional conflict and comity considerations raised by a broad extraterritorial assertion of U.S. regulatory law in this area, this Article urges countries to seek a multilateral solution to the problems raised by transnational securities fraud.

\footnotetext{
${ }^{1}$ While the regulatory systems of most countries with a developed securities market include proscriptions against fraud, there are broad variations in the intensity and methods of enforcement from one country to another. See John C. Coffee, Jr., Law and the Market: The Impact of Enforcement 4 (Columbia Univ. Sch. of Law, Ctr. for Law \& Econ. Studies, Working Paper No. 304, 2007); Howell E. Jackson, Variations in the Intensity of Financial regulation: Preliminary Evidence and Potential Implications, 24 YALE J. REG. 253, 256 (2007).

2 See Hannah L. Buxbaum, Multinational Class Actions Under Federal Securities Law: Managing Jurisdictional Conflict, 46 COLUM. J. TRANSNAT’L L. 14, 63-64 (2007).
} 
In supporting this position, Part I of this Article will provide background on U.S. securities antifraud rules and the global economy, emphasizing the challenge of addressing transnational securities fraud with primarily local regulatory tools. Part II will then set forth the current state of the law regarding the extraterritorial application of the U.S. securities antifraud provisions. Part III will examine the Second Circuit's recent application of the "conduct" test in the noteworthy case of Morrison v. National Australia Bank. ${ }^{3}$ It will also point out the problems with the current approach of courts in determining the extraterritorial reach of the securities antifraud rules in the context of so called foreign-cubed cases such as Morrison. Part IV will address possible solutions to these problems. This Article will then conclude by arguing for a multilateral framework that would enhance cooperation and establish minimum standards for regulating securities fraud, as well as a jurisdictional or choice-of-law rule to avoid jurisdictional conflict and unnecessary overregulation.

\section{The Securities Antifraud Rules AND the Global ECONOMY}

Federal regulation of securities transactions emerged in the aftermath of the 1929 stock market crash, with the aims of promoting "full and fair disclosure" in the sale of securities, protecting investors against fraud, and maintaining "fair and honest markets" for securities transactions. ${ }^{4}$ The securities laws achieve these goals through the implementation of a mandatory full disclosure policy under which market participants are required to reveal certain material information in connection with offers, sales, and purchases of securities, through proscriptions against fraud, and through the imposition of civil liabilities for violations of the securities laws and rules. ${ }^{5}$

Of course, much has changed in the American and global financial markets since the 1930s. Companies and investors alike participate in markets outside their own home base to an extent probably undreamed of at the time these U.S. securities laws were written. And yet, financial regulation remains largely bound by national borders, though cooperation between regulators has increased. ${ }^{6}$ At the same time, however, fraud in the financial markets is not constricted by national boundaries, as the recent unmasking of several global financial scandals has shown. ${ }^{7}$ In addition, though most developed countries prohibit securities fraud in similar substantive

3 Morrison v. Nat’l Austl. Bank Ltd., 547 F.3d 167 (2d Cir. 2008).

${ }^{4}$ See 15 U.S.C. § 77(a) (2010); 15 U.S.C. § 78(b) (2010); see also Michael J. Calhoun, Tension on the High Seas of Transnational Securities Fraud: Broadening the Scope of United States Jurisdiction, 30 LoY. U. CHI. L.J. 679, 682 (1999).

${ }^{5}$ See Calhoun, supra note 4, at 683.

${ }^{6}$ See, e.g., Catrin Griffiths, SEC Beefs Up Cross-Border Cooperation in Blitz on Fraud, THE LAWYER, Sept. 21, 2009, http://www.thelawyer.com/sec-beefs-up-cross-bordercooperation-in-blitz-on-fraud/1002023.article.

7 See Technical Comm. of the InT’L Org. Of Sec. Comm’ns., Strengthening Capital MARKETS AgAinst FinANCIAL Fraud iii (2005), http://www.iosco.org/library/pubdocs/pdf/ IOSCOPD192.pdf (hereinafter IOSCO, Financial Fraud). 
terms, ${ }^{8}$ significant differences exist in the manner such rules are enforced and the remedies that are available. ${ }^{9}$ The United States, in particular, is viewed as having one of the broadest prohibitions on securities fraud, in addition to having a relatively accessible mechanism for private enforcement. ${ }^{10}$ For this reason, foreign investors are increasingly seeking to initiate lawsuits in U.S. courts against alleged violators of U.S. antifraud rules. ${ }^{11}$

\section{A. Rule 10b-5: The Catch-All Antifraud Provision}

One reason for the popularity of the U.S. antifraud regime among litigants is the breadth of its most important antifraud provision, Rule 10b-5 of the Securities Exchange Act of 1934 (the "Exchange Act"). ${ }^{12}$ This securities regulatory regime seeks to prevent and punish fraud via numerous provisions in both the Securities Act of $1933^{13}$ and the Exchange Act. However, the most far-reaching of these provisions is Section 10(b) of the Exchange Act and its accompanying Rule 10b-5. The Supreme Court has characterized Section 10(b) as a "catch-all" provision. ${ }^{14}$ It is not restricted to fraud in connection with sales or transactions in the United States, but rather applies to the use of manipulative or deceptive devices or contrivances "in connection with the purchase or sale of any security registered on a national securities exchange or any security not so registered," so long as the means of interstate commerce are implicated. ${ }^{15}$ Courts, in interpreting the language and legislative history of Section 10(b), have determined that "Congress thus meant $\S$ 10 (b) to protect against fraud in the sale or purchase of securities whether or not these were traded on organized United States markets." 16

In 1942, the Securities and Exchange Commission (“SEC”) used its rule-making authority under Section 10(b) to promulgate Rule 10b-5. Rule 10b-5 makes it unlawful:

${ }^{8}$ Compare, for example, the prohibition in Rule 10b-5 to Trade Practices Act, 1974, c. 52 (Austl.) (prohibiting a corporation from engaging in conduct in trade or commerce that "is misleading or deceptive or is likely to mislead or deceive”).

${ }^{9}$ See, e.g., Hannah L. Buxbaum, Competition in the Private Enforcement of Regulatory Law 2 (Indiana University School of Law - Bloomington Working Paper Series, 2008) (available at SSRN: http://ssrn.com/abstract=1129832) (hereinafter Buxbaum, Competition).

${ }^{10}$ See id. at 1; see also Joshua G. Urquhart, Transnational Securities Fraud Regulation: Problems and Solutions, 1 CHI. J. INT'L L. 471, 473 (2000) (characterizing the US system as the most "plaintiff-friendly").

${ }^{11}$ Buxbaum, supra note 2, at 16-17.

1215 U.S.C. §§ 78j(b) and Rule 10b-5 promulgated thereunder, 17 C.F.R. § 240.10b-5 (1951).

${ }^{13} 15$ U.S.C. § 78a et seq. (1934).

${ }^{14}$ Ernst \& Ernst v. Hochfelder, 425 U.S. 185, 203 (1976).

${ }^{15} 15$ U.S.C. § 78j(b) (2010) (emphasis added).

${ }^{16}$ Leasco Data Processing Equip. Corp. v. Maxwell, 468 F.2d 1326, 1336 (2d Cir. 1972). 
for any person, directly or indirectly, by the use of any means or instrumentality of interstate commerce, or of the mails or of any facility of any national securities exchange,

a. To employ any device, scheme, or artifice to defraud,

b. To make any untrue statement of a material fact or to omit to state a material fact necessary in order to make the statements made, in the light of the circumstances under which they were made, not misleading, or

c. To engage in any act, practice, or course of business which operates or would operate as a fraud or deceit upon any person, in connection with the purchase or sale of any security. ${ }^{17}$

The language of the rule is not only unquestionably far reaching, but also vague. The details of its application and scope were left almost exclusively for the courts to determine, generating extensive judicial discussion. ${ }^{18}$ With the increasing integration of the world financial markets, one of the key questions with regards to Rule 10b-5, in judicial, academic, and practitioner circles, has been the scope of its extraterritorial application. The debate centers on the issue of how to properly delineate this scope so as to prevent and punish fraud, without discouraging companies from transacting in the United States or with U.S. persons, and without causing conflict with other nations' interests in regulating the activity.

\section{B. Lawsuits Under the Antifraud Rules and "Foreign-Cubed" Cases}

Rule 10b-5 has no explicit civil remedy for its violation, but an implied private right of action has been well established for some time. ${ }^{19}$ In affirming the finding of an implied private right of action under 10b-5, the Supreme Court has noted that "private enforcement of Commission rules may '[provide] a necessary supplement to Commission action'”20 in carrying out the purposes of Section 10(b) and Rule 10b-5. Commentators have affirmed this position, noting that a private enforcement mechanism provides a strong form of ex-post regulation that allows relatively lax exante regulation, a central characteristic of the U.S. securities regulatory system. ${ }^{21}$ The class action mechanism for lawsuits further strengthens the deterrent effect of the private enforcement regime, combating the collective action problem presented

\footnotetext{
1717 C.F.R. § 240.10b-5 (2010).

${ }^{18}$ See Loss \& Seligman, Fundamentals of Securities Regulation 3477 (3rd ed. 2003) (noting that "it is difficult to think of another instance in the entire corpus juris in which the interaction of the legislative, administrative rulemaking, and judicial processes has produced so much from so little,” and quoting Chief Justice Rehnquist who has called 10b-5 a "judicial oak which has grown from little more than a legislative acorn”).

${ }^{19}$ Ernst \& Ernst, 425 U.S. at 196. It is also by now a common occurrence for class action lawsuits to be brought under Rule 10b-5, and the SEC may also bring suit against violators for the imposition of fines and/or injunctions.

${ }^{20}$ Blue Chip Stamps v. Manor Drug Stores, 421 U.S. 723, 730 (1975) (quoting J. I. Case Co. v. Borak, 377 U.S. 426, 432 (1964)).

${ }^{21}$ Samuel Isaacharoff, Regulating After the Fact, 56 DePAUL L. REV. 375, 380-82 (2007).
} 
by securities fraud perpetrated on widely dispersed shareholders. ${ }^{22}$ In contrast, private litigation of securities fraud is less common in other countries, which rely more heavily on government regulators to enforce their securities laws. However, securities fraud litigation is catching on in other places, including Australia, Europe, and China. ${ }^{23}$

In the context of globalized financial markets, securities fraud litigation in U.S. courts raises complex questions about the extraterritorial application of securities laws. It is very rare to find a modern securities fraud case that does not have an international facet of some kind, be it a case against a foreign issuer whose shares are traded on an American exchange, ${ }^{24}$ a suit against an American company who sells its shares both in the United States and abroad, ${ }^{25}$ or a suit against a foreign company who orchestrates a fraud in the United States, for example via its American subsidiary. ${ }^{26}$ One particular genre of cases that has been presented with increasing frequency is the so-called "foreign-cubed" cases. ${ }^{27}$ These cases involve (1) a foreign investor who purchased the securities (2) of a foreign corporation (3) in a foreign transaction. ${ }^{28}$ At first blush, these cases are predicated on transactions having little to do with the United States, and it seems hardly surprising that courts would decline to apply U.S. law to them. Certainly, they do present the outermost limit of the extraterritorial application of U.S. securities laws. However, courts have recognized that there are some instances in which these cases should be heard in the United States, as will be discussed in greater detail in Part III, infra.

Evidence suggests that cases implicating the extraterritoriality of U.S. securities laws are becoming increasingly common. ${ }^{29}$ A study of securities fraud class actions

\footnotetext{
${ }^{22}$ Ilana T. Buschkin, The Viability of Class Action Lawsuits in a Globalized Economy Permitting Foreign Claimants to be Members of Class Action Lawsuits in the U.S. Federal Courts, 90 CORNELL L. REV. 1563, 1564-65 (2005).

${ }^{23}$ See, e.g., Olivier Cavézian, et. al., Class Actions in Europe: Reality or Myth? The Example of France, JONES DAY (Oct. 2009), available at http://www.jonesday.com/ files/Publication/ff7fd833-8640-443cbb46d6e756864345/Presentation/PublicationAttachment/ 6e60f00f-0d2a-4c0c-b986-d7982522c1f6/Class\%20Actions\%202009.pdf; Jonathan Redwood, Limitations of U.S. Securities Litigation Against Australian Companies by Australian Plaintiffs, LIST A BARRISTER PUBLICATIONS (Dec. 2008), available at http://www. barristers.com.au/www/392/1001127/displayarticle/recent-publications1001461.html; Chao Xi, Private Enforcement of Securities Law in China: Daqing Lianyi Co v. Zhong Weida and Others (2004) Heilongjiang High Court, 1 J. ComP. L. 492 (2006), available at http://papers.ssrn.com/sol13/papers.cfm?abstract_id=965635.
}

${ }^{24}$ See, e.g., Schoenbaum v. Firstbrook, 405 F.2d 200 (2d Cir. 1968).

${ }^{25}$ See Mohanty v. Bigband Networks, Inc., Fed. Sec. L. Rep. (CCH) P94, 581 (2008).

${ }^{26}$ See In re Gaming Lottery Sec. Litig., 58 F. Supp. 2d 62 (S.D.N.Y. 1999).

${ }^{27}$ Buxbaum, supra note 2, at 17.

${ }^{28}$ See Stuart M. Grant \& Diane Zilka, The Current Role of Foreign Investors in Federal Securities Class Actions, 1620 PLI/CORP. 11 (2007). Grant and Zilka are generally credited with coining the term "foreign-cubed."

${ }^{29}$ See, e.g., Brief of the Securities Exchange Commission as Amicus Curiae, in Response to the Court's Request at 4-5, Morrison v. Nat'l Australia Bank, 547 F.3d 167 (2d Cir. 2008) (No. 07-0583-CV) (hereinafter SEC Brief). 
found that they have generally been on the rise in recent years, particularly as a byproduct of the sub-prime crisis and the global financial crisis, with actions against foreign issuers hitting an all-time high in $2008 .^{30}$ This provides both a challenge and an opportunity for examination of the still unsettled law on the extraterritorial application of U.S. securities laws.

\section{EXTRATERRITORIAL APPLICATION OF THE U.S. SECURITIES ANTIFRAUD RULES}

The Exchange Act is generally silent as to the extraterritorial application of its antifraud provisions, except that Section 10(b) limits its reach to prohibited actions using the "means or instrumentality of interstate commerce or of the mails." 31 Given modern technology and the global nature of financial markets, this provision could technically encompass a broad range of transactions having little or nothing to do with the United States. However, the breadth of the antifraud provision is tempered by a general presumption against extraterritorial application of U.S. law $^{32}$ and principles of international comity. Though it is clear that Congress, in its broad wording of the antifraud provisions, intended some form of extraterritorial application, it has left the task of outlining the scope of their extraterritorial application to the courts.

\section{A. The Restatement (Third) of Foreign Relations Law}

Historically, application of regulatory laws was limited by the principle of territoriality, as articulated in the Supreme Court's famous American Banana case. ${ }^{33}$ However, the extraterritorial application of regulatory laws is now widely accepted, though there remains a debate as to the proper scope and justifications for such application. $^{34}$ The Restatement (Third) of Foreign Relations Law, drawing on principles of customary international law, provides some guidance as to the proper extraterritorial reach of U.S. regulatory law. It defines jurisdiction to prescribe as the power of a country to "make its law applicable to the activities, relations, or status of persons, or the interests of persons in things." ${ }^{35}$ The Restatement goes on to set forth the following bases of jurisdiction: conduct that, wholly or in substantial part, takes place within its territory; and conduct outside its territory that has or is intended to

${ }^{30}$ See, e.g., Grace Lamont \& Patricia A. Etzold, 2008 Securities Litigation Study, PriceWATERHOUSE COOPERS Apr. 1, 2009, http://10b5.pwc.com/PDF/NY-09-0894\%20 SECURITIES\%20LIT\%20STUDY\%20FINAL.PDF. It is important to note that class actions are treated differently than other private actions or SEC enforcement actions in regard to the question of the extraterritorial application of the securities laws.

31 U.S.C. § 78j (2010).

32 Equal Employment Opportunity Comm’n v. Arabian Am. Oil Co., 499 U.S. 244, 248 (1991). "It is a longstanding principle of American law 'that legislation of Congress, unless a contrary intent appears, is meant to apply only within the territorial jurisdiction of the United States.”' (quoting Foley Bros., Inc. v. Filardo, 336 U.S. 281, 284-85 (1949)).

33 Am. Banana Co. v. United Fruit Co., 213 U.S. 347, 357 (1909).

${ }^{34}$ See, e.g., Andrew T. Guzman, Choice of Law: New Foundations, 90 GEO. L.J. 883 (2002) (hereinafter Guzman, New Foundations).

${ }^{35}$ Restatement (ThiRd) OF Foreign RELAtions LAW § 401 (1987) (hereinafter Restatement 3rd). 
have substantial effect within its territory. ${ }^{36}$ These two bases of jurisdiction are reflected in the court-developed approaches known as the "conduct" and "effects" tests, discussed below.

Even when one of the aforementioned bases for jurisdiction is minimally present, the Restatement requires that the exercise of jurisdiction must be reasonable. ${ }^{37}$ Drawing on the interest balancing approach of modern choice-of-law analysis, it sets forth certain factors that should inform the reasonableness inquiry, such as the relative interests of the States whose regulatory regimes are implicated, overall contacts with the country seeking to exercise jurisdiction, and reasonable expectations of the parties. ${ }^{38}$

With respect to U.S. securities laws in particular, the Restatement has more to say, asserting that jurisdiction exists with regards to "conduct occurring predominantly in the United States that is related to a transaction in securities, even if the transaction takes place outside the United States." 39 This is a fairly broad assertion of jurisdiction to prescribe, reflecting the policy articulated in the Restatement that "an interest in punishing fraudulent or manipulative conduct is entitled to greater weight than are routine administrative requirements." ${ }^{40}$ However, the extent of jurisdiction to prescribe under the Restatement is considered the outer limit of the legislature's extraterritorial reach, and courts have generally declined to interpret Congress' intent as having reached those outer limits in the context of U.S. securities antifraud rules. ${ }^{41}$

The Restatement, like the judicially-developed "conduct" and "effects" tests, reflects the need to balance a state's regulatory interest against considerations of international comity as well as an interest in preserving limited judicial resources. ${ }^{42}$ Principles of comity dictate that courts consider whether an exercise of U.S. jurisdiction in a particular case will conflict with or infringe upon the regulatory interests of another nation. ${ }^{43}$ Further, case law has recognized that, though a

${ }^{36} I d$.

${ }^{37}$ Id. $\S 403$.

${ }^{38}$ Id. § 403(2)(a)-(h); see also, Stephen J. Choi \& Linda J. Silberman, Transnational Litigation and Global Securities Class Actions Lawsuits, 2009 WIS. L. REV. 465, 477 (2009).

${ }^{39}$ Restatement (THIRD) OF Foreign RELATIONS LAW § 416(1)(d) (1987).

${ }^{40}$ Id. $\S 416$ cmt. a (1987).

${ }^{41}$ Leasco, 468 F.2d at 1334.

${ }^{42}$ The policies of avoiding jurisdictional conflict and preserving U.S. judicial resources have been articulated frequently by the courts in cases addressing extraterritorial application of the securities laws. See, e.g., Bersch v. Drexel Firestone, 519 F.2d 974, 985 (2d Cir. 1975). However, it is worth noting that these considerations are also addressed by other tools of the courts besides jurisdictional inquiries, such as discretionary dismissals on the bases of forum non conveniens and comity. Buxbaum, supra note 2, at 64-65.

${ }^{43}$ The Supreme Court has articulated comity as "neither a matter of absolute obligation, on the one hand, nor of mere courtesy and good will, upon the other. But it is the recognition which one nation allows within its territory to the legislative, executive or judicial acts of another nation, having due regard both to international duty and convenience, and to the rights of its own citizens or of other persons who are under the protection of its laws." Hilton v. Guyot, 159 U.S. 113, 163-64 (1895). 
regulatory interest may exist, if a transaction is "predominantly foreign," the court "must seek to determine whether Congress would have wished the precious resources of the United States courts and law enforcement agencies to be devoted to them rather than leave the problem to foreign countries." ${ }^{44}$ These considerations must be taken into account when courts consider whether an alleged fraud bears a sufficient connection to the United States to warrant application of U.S. antifraud rules.

\section{B. The Conduct and Effects Tests}

Because of its location at the center of the financial markets, the Second Circuit has been the most influential court in terms of the development of jurisprudence in this area. Though, other courts have sometimes deviated from the Second Circuit's approach. ${ }^{45}$ The Second Circuit has developed two tests to determine whether U.S. securities laws should apply extraterritorially: the conduct test and the effects test. Application of the antifraud rules may be found on the basis of either test, or on an admixture of the two. ${ }^{46}$ The effects test focuses on whether U.S. investors or markets were harmed by the alleged fraud. This will typically be the case, for example, where a foreign company's stock trades on a U.S. market. ${ }^{47}$ The key limitation to the effects test is that courts do not consider foreign conduct with only generalized effects in the United States to be sufficient. ${ }^{48}$ Rather, courts require a showing of harm to specific interests within the United States. ${ }^{49}$

The conduct test looks at whether some conduct that was material to the alleged fraud directly caused the harm in question, regardless of the location of the investors or the markets where the stock was sold. ${ }^{50}$ The conduct test, while more soundly rooted in the traditional basis of territoriality than the effects test, has proven to be more difficult to apply than the effects test. The main difficulty is determining what level of conduct in the U.S. is sufficient to warrant jurisdiction under the Exchange Act. Securities transactions can be made up of many moving parts that often cross territorial boundaries and fraudulent acts can occur in more than one place. ${ }^{51}$ The Second Circuit addressed this question in Bersch v. Drexel Firestone, Inc., asserting

\footnotetext{
${ }^{44}$ Bersch, 519 F.2d at 985.

${ }^{45}$ See, e.g., Zoelsch v. Arthur Andersen \& Co., 824 F.2d 27, 32 (D.C. Cir. 1987); see also Russell J. Weintraub, The Extraterritorial Application of Antitrust and Securities Law: An Inquiry into the Utility of a "Choice-of-Law” Approach, 70 TEX. L. REV. 1799, 1812 (1992).

${ }^{46}$ Itoba Ltd. v. LEP Group PLC, 54 F.3d 118, 121-22 (2d Cir. 1995).

${ }^{47}$ This was so in the first case to articulate the effects test. Schoenbaum v. Firstbrook, 405 F.2d 200 (2d Cir. 1968).

${ }^{48}$ Buxbaum, supra note 2, at 22.

${ }^{49}$ See id. at 22-3 (citing Interbrew S.A. v. Edperbrascan Corp., 23 F. Supp. 2d 425, 430 (S.D.N.Y. 1998)).

${ }^{50}$ Bersch, 519 F.2d at 993 (asserting that U.S. securities laws apply to losses from sales of securities to foreigners outside the United States only when acts or culpable failures to act within the United States directly caused such losses).

${ }^{51}$ See Stephen J. Choi \& Andrew T. Guzman, The Dangerous Extraterritoriality of American Securities Law, 17 Nw. J. INT’L L. \& Bus. 207, 216-17 (1996).
} 
that U.S. securities laws only apply to losses from sales of securities to foreigners outside the United States when acts or culpable failures to act directly caused such losses. $^{52}$ Lesser thresholds of conduct are necessary when conduct causes losses in the United States (no U.S. conduct is necessary), or to Americans residents abroad (acts or omissions in the United States must have "significantly contributed" to such losses). ${ }^{53}$ The Bersch standard relating to conduct causing losses to foreigners has been further refined to hold that subject matter jurisdiction exists over securities claims if "activities in [the United States] were more than merely preparatory to a fraud and culpable acts or omissions occurring here directly caused losses to investors abroad." 54 Of course, this still begs the questions of what is "merely preparatory" and what constitutes "directly caused"; lower courts have struggled with these questions, and the Second Circuit itself has provided little guidance.

\section{A Procedural Note}

Courts have always treated the question of extraterritorial application of the securities antifraud provisions as a question of subject matter jurisdiction..$^{55}$ However, this is somewhat of a misnomer as the real question is one of jurisdiction to prescribe ${ }^{56}$ or rather, whether or not the allegedly fraudulent acts fall within the ambit of U.S. securities antifraud rules. ${ }^{57}$ The Supreme Court recently criticized the "less-than-meticulous" treatment by courts of the distinction between an element of a claim for relief under federal law and a limitation on subject matter jurisdiction. ${ }^{58}$ To remedy this, the Supreme Court in Arbaugh v. T \& H Corp. ${ }^{59}$ drew a bright-line rule holding that "when Congress does not rank a statutory limitation on coverage as jurisdictional, courts should treat the restriction as nonjurisdictional in character." 00 Even though the controversy before the Supreme Court was a Title VII claim, the Court did not reserve its new bright-line rule to a particular context. Further, lower courts have acknowledged that the rule from Arbaugh is applicable in the context of extraterritorial application of U.S. securities laws. ${ }^{61}$

The jurisdictional limitation articulated by courts in these cases reflected a "recognition by the courts that Congress would not have wished 'the precious resources of United States courts and law enforcement agencies' to be spent on

52 Bersch, 519 F.2d at 993.

${ }^{53} I d$.

${ }^{54}$ Morrison v. Nat'l Austl. Bank Ltd., 547 F.3d 167, 171 (2d Cir. 2008).

${ }^{55}$ See Bersch, 519 F.2d at 984-90.

${ }^{56}$ Restatement (ThiRd) OF the Foreign Relations LaW OF the United States $§ 401$ (1987) (defining jurisdiction to prescribe as the power of a country to "make its law applicable to the activities, relations, or status of persons, or the interests of persons in things").

${ }^{57}$ See also ANDREAs LOWENFELD, INTERNATIONAL LiTIGATION \& ARBITRATION 55 (3rd ed. 2005).

${ }^{58}$ Arbaugh v. T \& H Corp., 546 U.S. 500, 511 (2006).

${ }^{59}$ Id. at 500.

${ }^{60}$ Id. at 516.

${ }^{61}$ See In re Parmalat Securities Litig., 497 F. Supp. 2d 526, 529 (S.D.N.Y. 2007). 
predominantly foreign transactions." ${ }^{22}$ While the recognition is valid, the question is not one of subject matter jurisdiction of the courts. Instead, the Court's statement in Arbaugh clarifies that the inquiry should be one of a plaintiff's entitlement to relief under relevant provisions of the Exchange Act. Jurisdiction over lawsuits alleging violations of Section 10(b) and Rule 10b-5 is conferred by Section 27 of the Exchange Act. ${ }^{63}$ The location of fraudulent conduct, therefore, does not affect this conferral of jurisdiction. It is only relevant as to whether or not a particular fraudulent scheme or act violates Section 10(b). Section 10(b) does not apply if no use of the means or instrumentalities of interstate commerce was made. ${ }^{64}$ Further, courts have long recognized that the federal securities laws do not reach the outer limit of Congress' power to impose civil liabilities (which is constrained only by constitutional due process considerations). ${ }^{65}$ Therefore, a fraudulent scheme must have sufficient connection to the United States in order to be covered by the substantive prohibitions of Section 10(b).$^{66}$

There is an additional way in which the location of fraudulent acts in connection with the sale or purchase of securities can be relevant. The private right of action for Section 10(b) requires that a claim by a private plaintiff, as opposed to a suit brought by the SEC, must allege a causal connection between their injury and the plaintiff's conduct. ${ }^{67}$ Therefore, where application of Section 10(b) and Rule 10b-5 to a particular fraudulent scheme is predicated solely on conduct within the United States, foreign private plaintiffs could be required to show a causal connection between the U.S. conduct and their alleged injuries. ${ }^{68}$ Such an approach would be in keeping with the Supreme Court's approach to the extraterritorial application of U.S. antitrust laws. ${ }^{69}$ While making the distinction between a jurisdictional inquiry and a failure-to-state-a-claim inquiry may have minimal impact on the outcome of most cases, it does make clear the distinction between the standard that must be met by private plaintiffs in a class action lawsuit versus the standard that must be met by the SEC in an enforcement action. ${ }^{70}$ In cases involving parallel claims by foreign private litigants and the SEC, this distinction is important, as courts using the subject matter

${ }^{62}$ Id. (citing Bersch v. Drexel Firestone, Inc., 519 F.2d 974, 985 (2d Cir. 1975)).

6315 U.S.C. § 78a (2009).

${ }^{64}$ See 15 U.S.C. § 78j (2009); see also supra text accompanying notes 13-15.

${ }^{65}$ See Leasco, 468 F.2d 1334.

${ }^{66}$ See Brief for the United States as Amicus Curiae Supporting Respondents at 11-12, Morrison v. Nat'l Austl. Bank Ltd., 129 S.Ct. 2762 (2009) (No. 08-1191), 2010 WL 719337 [hereinafter Brief of Solicitor General].

${ }^{67}$ See, e.g., Basic Inc. v. Levinson, 485 U.S. 224, 243 (1988).

${ }^{68}$ Brief of Solicitor General, supra note 66, at 10-11.

${ }^{69}$ See F. Hoffmann-La Roche Ltd. v. Empagran S.A., 542 U.S. 155 (2004).

${ }^{70}$ Courts have recognized that a stricter standard is appropriate for extraterritorial application of U.S. law in the context of class actions. See Bersch v. Drexel Firestone, Inc., 519 F.2d 974, 987 (2d Cir. 1975) (noting that "Congress did not mean the United States to be used as a base for fraudulent securities schemes even when the victims are foreigners, at least in the context of suits by the SEC or by named foreign plaintiffs" (emphasis added)). 
jurisdiction inquiry have historically dismissed both actions if they find an insufficient connection between the U.S. conduct and the alleged harm. ${ }^{71}$

\section{The Conduct Test in Focus: Foreign-Cubed CAses And the Problems of UNDER AND OVERREGULATION}

The conduct test has been applied frequently in recent years. With the increasing incidence of transnational securities fraud, investors have become more proactive in seeking redress. Often this leads them to the United States, with its well-developed class action mechanism in securities fraud cases. ${ }^{72}$ Courts have begun to hear socalled foreign-cubed cases with increasing frequency. ${ }^{73}$ Such cases test the outer limits of the extraterritorial application of U.S. antifraud rules on the basis of the conduct test, and also highlight the problems with the current approach of courts with respect to this issue.

\section{A. Morrison v. National Australia Bank}

A recent foreign-cubed case decided by the Second Circuit underscored the particular difficulties raised by this kind of case and reignited debate on the proper scope of the extraterritorial application of U.S. laws on the basis of conduct. The impetus for Morrison v. National Australia Bank was a series of write-downs made by National Australia Bank ("NAB") in 2001, due to the allegedly fraudulent overvaluation of one of NAB's American subsidiaries, HomeSide, Inc., a Floridabased mortgage servicing company. ${ }^{74}$ The write-downs totaled approximately $\$ 4$ billion. ${ }^{75}$ It constituted the largest loss reported in Australian corporate history up to that point. ${ }^{76}$ NAB's shares, trading on the Australian Stock Exchange, as well as on exchanges in Tokyo, New Zealand, London, and in the form of American Depositary Receipts ("ADRs") on the New York Stock Exchange, initially dropped between $10 \%$ and $13 \%$ following the write-downs. ${ }^{77}$

In response to these losses, a group of international shareholders of the bank brought a lawsuit against NAB in U.S. federal court, claiming violations of the securities antifraud rules including Rule 10b-5. The plaintiffs alleged that the

\footnotetext{
${ }^{71}$ See generally, e.g., Morrison, 547 F.3d 167.

${ }^{72}$ See PriceWaterhouse Coopers, 2008 Securities Litigation Study, April 1, 2009, http://10b5.pwc.com/PDF/NY-09-0894\%20SECURITIES\%20LIT\%20STUDY\%20FINAL .PDF (noting that securities class actions against foreign issuers hit an all-time high in 2008).

${ }^{73}$ Buxbaum, supra note 2, at 17.

${ }^{74}$ Morrison, 547 F.3d 167.

75 “A\$” denotes Australian dollars. According to statistics of the Reserve Bank of Australia, the Australian dollar was worth approximately 0.53 US dollars on the date of NAB's announcement of its second HomeSide-related write-down.

${ }^{76}$ Shann Turnbull, Men Behaving Badly in Banking: Revealing the Irrelevance of Best Practices in Corporate Governance, in GoverNANCE, RISK AND COMPLIANCE HANDBOOK: TECHNOLOGY, FINANCE, ENVIRONMENTAL, AND INTERNATIONAL GUIDANCE AND BEST PRACTICES 82, 83 (Anthony G. Tarantino ed., 2008), available at http://media.wiley.com/product_ancillary/ 9X/04700958/DOWNLOAD/chapter73.pdf.

${ }^{77}$ Brief of Appellant-Petitioner at 19, Morrison v. Nat'l Austl. Bank Ltd., 547 F.3d 167 (2d Cir. 2008) (No. 07-0583-CV) [hereinafter Appellants’ Brief].
} 
overvaluation of HomeSide was the result of intentional misuse of valuation models by certain NAB employees and executives who "had been cooking HomeSide's books since at least April 1999," in violation of the U.S. securities laws. ${ }^{78}$ These misstatements of HomeSide's value were sent to NAB's headquarters in Australia and incorporated into its consolidated financial statements, then disseminated to the public in regulatory filings and press releases, including filings with the SEC made in connection with NAB's ADRs. ${ }^{79}$

Although calling the case a "close call," the District Court dismissed the case, stating that "the transactions of which the plaintiffs complain [are] fundamentally foreign in nature, and thus beyond the scope of this Court's jurisdiction under the Exchange Act.” ${ }^{\prime 0}$ On appeal, the Second Circuit affirmed the District Court's outcome. ${ }^{81}$ However, the Second Circuit left open the possibility that, on other facts, it would hear a foreign-cubed claim by foreign plaintiffs. ${ }^{82}$ Defendants had argued for a bright-line rule barring foreign-cubed claims brought solely on the basis of conduct in the United States, if there was no allegation of harm to domestic investors or markets. ${ }^{83}$ The Second Circuit refused to adopt such a rule, because it could not anticipate "all the circumstances in which the ingenuity of those inclined to violate the securities laws should result in their being subject to American jurisdiction." ${ }^{84}$ Instead, the Second Circuit determined that the conduct and effects tests were the proper lens through which to examine the question of extraterritoriality. ${ }^{85}$ It went on to say that the issue before it in Morrison "boils down to what conduct comprises the heart of the alleged fraud." 86 On the facts of the case, though, the Second Circuit found that acts or omissions in Australia were "more directly responsible" for the plaintiffs' injuries, and declined to exercise jurisdiction over the case. ${ }^{87}$

Morrison was the Second Circuit's first look at a foreign-cubed case, and although it did not find a sufficient basis for the application of U.S. securities laws, numerous district court decisions have come out the other way. For example, In re Gaming Lottery involved claims by both U.S. and foreign plaintiffs against a Canadian corporation for fraud in connection with the sale of securities on both American and Canadian exchanges. ${ }^{88}$ The relevant U.S. conduct included the acquisition of a Washington corporation which the defendant company proceeded to operate without receiving regulatory approval from Washington State gaming

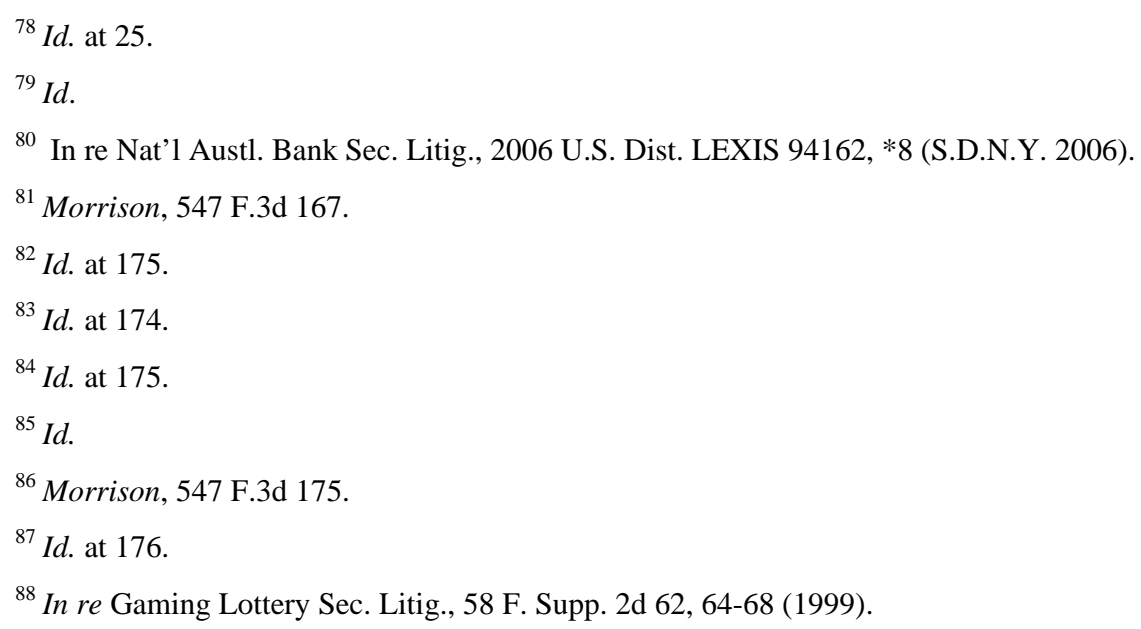


regulators for operations. ${ }^{89}$ In addition, the company reported increases in earnings and stockholder equity based on the acquired entity's financials, even though they knew they would not be able to obtain regulatory approval for the entity's operations, therefore making the statements regarding the U.S. subsidiary's earnings misleading. ${ }^{90}$ The United States District Court for the Southern District of New York certified both Canadians and U.S. investors as lead plaintiffs, ${ }^{11}$ finding that sufficient conduct had occurred in the United States that was "more than merely preparatory" to the alleged fraud so as to confer subject matter jurisdiction over the claims of both Canadian and domestic plaintiffs. ${ }^{92}$

Similarly, in In re Vivendi Universal, the issuing company's Chief Executive Officer (“CEO”) and Chief Financial Officer (“CFO”) moved to New York in order to oversee a number of acquisitions of U.S. companies. It was debt taken on in connection with these acquisitions that was the focus of the allegedly false and misleading statements at issue in the lawsuit. ${ }^{93}$ The U.S.-based conduct was, therefore, the basis for the false statements, and was found to be "integral and not merely preparatory to the alleged fraud upon foreign purchasers of Vivendi shares on foreign exchanges." ${ }^{\text {94 }}$

Comparing the facts of these cases to Morrison, it seems clear that Morrison could have easily come out the other way. ${ }^{95}$ Indeed, the judge in In re Gaming Lottery might well have found for plaintiffs in Morrison. Although the Second Circuit claimed to be applying its "usual rules," 96 the court struggled with the issue of whether the conduct in the U.S. had "directly caused" the harm abroad. The Second Circuit used novel language to find that acts or omissions in Australia were "more directly responsible" for the plaintiffs' injuries. ${ }^{97}$ This simple addition of the word "more" had the effect of changing the inquiry to a question of which acts, on balance, more directly caused the alleged fraud. Under the usual articulation of the test, it is quite possible that conduct in more than one place could directly cause the alleged harm. Certainly, the Restatement and customary international law both contemplate concurrent jurisdiction in some circumstances. ${ }^{98}$ The Second Circuit's

\footnotetext{
${ }^{89}$ Id. at $65-67$.

${ }^{90} I d$.

${ }^{91}$ The process of appointing a lead plaintiff in multinational securities class actions often invokes the question of the extraterritorial application of the US antifraud rules. See Buxbaum, supra note 2, at 27-29.

${ }^{92}$ In re Gaming Lottery, 58 F. Supp. 2d at 73-74.

${ }^{93}$ In re Vivendi Universal SA, 2004 U.S. Dist. LEXIS 21230, *6 (S.D.N.Y. 2004).

${ }^{94}$ Id. at 14 .

${ }^{95}$ See Choi \& Silberman, supra note 38, at 492 (noting that, “another court, analyzing the same facts, may have decided the case differently ....”).

${ }^{96}$ Morrison, 547 F.3d at 172.

${ }^{97}$ Id. at 176 (emphasis added).

${ }^{98}$ P.M. Roth, Reasonable Extraterritoriality: Correcting the "Balance of Interests”, 41 INT’L \& COMP. L.Q. 245, 253 (1992).
} 
"more directly" language had never appeared in any prior case, making it seem like the Court was straining to avoid exercising jurisdiction in this case.

Furthermore, the Second Circuit never said that the actions taken in the U.S. were not directly responsible for the losses to investors abroad, but only that the actions in Australia were a more direct cause, essentially introducing a balancing test into the analysis where none had previously existed. Such a balancing approach is reminiscent of the approach taken by the Restatement, even though courts and commentators have generally eschewed the utility of a conflict-of-laws style interestbalancing approach to these cases. ${ }^{99}$ Furthermore, just because the activity abroad may have more directly caused the harm in a particular case, it should not necessarily dictate that a U.S. court has no jurisdiction to hear the case. Such an outcome could violate the spirit of U.S. securities laws and could leave defrauded investors without a remedy, even in cases where arguably grievous acts of fraud had occurred in the United States.

\section{B. The Problems of Under and Overregulation}

As the Second Circuit's decision in Morrison highlights, one of the key problems with the conduct test is that it is difficult to apply to modern securities fraud cases. Because of the case-by-case nature of the inquiry and the lack of uniformity among courts in interpreting the conduct test, cases with similar facts will often have disparate outcomes, without any clear indicators from courts as to what tips the balance one way or the other. In fact, rather than seeking to provide a clear set or hierarchy of factors, courts have cautioned against relying on any particular factor as a sufficient decisional guide. ${ }^{100}$ One reason for retaining a flexible test and shunning bright-line rules is to avoid providing a roadmap to fraud for opportunistic issuers. In fact, a concern expressed by the plaintiffs and the SEC as amicus curiae in the Morrison case was that the court's holding could "render superfluous the conduct test, in effect converting it into a 'from where the misstatements originated and emanated' test." 101 Such a standard could make it easier for foreign entities to structure transactions specifically to avoid application of the U.S. antifraud rules while still benefiting from the fraudulent conduct of their U.S. subsidiaries. ${ }^{102}$ Foreign issuers may in fact be doing so already. A practice note written by an Australian law firm following the Morrison decision advises issuer clients that they can limit exposure to U.S. litigation by "taking steps to ensure that . . . the issuance of [their] disclosures" occurs outside the United States. ${ }^{103}$

\footnotetext{
${ }^{99}$ See, e.g., Zoelsch, 824 F.2d at 32 n.2 ("[B]alancing tests . . . tend to deemphasize foreign sovereign interests and almost never lead a court to decline jurisdiction.”); see generally, Weintraub, supra note 45, at 1809.

${ }^{100}$ IIT, Int’l Inv. Trust v. Cornfeld, 619 F.2d 909, 918 (2d Cir. 1980).

101 Appellants’ Brief, supra note 77, at 38.

102 See id. at 38-9 (“[F]oreign entities with U.S. subsidiaries could brazenly turn a blind eye to their subsidiaries' misconduct while enjoying immunity from American securities laws regardless of how much misconduct occurred on U.S. soil - provided that the foreign entities create and disseminate their financial statements from abroad.”).

${ }^{103}$ Redwood, supra note 23.
} 
Apart from providing a roadmap to fraud for opportunistic issuers, too narrow an approach to extraterritoriality could result in under regulation, if no country has a sufficient basis or motivation for applying their law to a case. For example, an approach such as that used by the Morrison court that would apply U.S. law only where U.S. conduct comprises "the heart" of the fraud, could frequently result in instances where no law applies, as conduct may not predominate in any single jurisdiction. This kind of anarchy in terms of antifraud enforcement could negatively impact investor confidence in the securities markets.

In a world where fraud is not sufficiently deterred, or where adequate remedies are not available to defrauded investors, investor confidence in the integrity of securities markets will be compromised. ${ }^{104}$ This can have a negative effect on liquidity and prices in markets around the world. ${ }^{105}$ Recent decades have seen a dramatic increase in the integration and interdependence of world financial markets. Generally speaking, globalization along these lines is viewed as a positive thing, generating economic growth around the world. However the "flip side . . . is the problem of financial crises - the problem of lending booms and busts, massive capital inflows and equally massive reversals." ${ }^{106}$ A second aspect of this increasing integration of the world's financial markets is the global nature of modern securities fraud. For example, the revelation of the multi-billion-dollar international ponzi scheme run by Bernard Madoff epitomizes the truly global reach of modern securities fraud: from his base in New York, Madoff sold his scheme to investors on nearly every continent. Victims ranged from the major Spanish bank Santander to a Korean pension fund to a synagogue in New York to the International Olympic Committee. ${ }^{107}$ Fraud such as this can and does negatively impact investor confidence, slowing investment flows around the world. ${ }^{108}$

All of this complicates the work of financial regulators, who must seek to regulate the increasingly complex and integrated securities markets and prevent fraud that stretches across borders, without overstepping the traditionally territorial mandate of regulatory law, and without over-regulating, which causes costly inefficiencies. In the words of one SEC commissioner:

Our mission to facilitate capital formation extends not just to companies headquartered in the United States, but to those from outside the country as well .... We must be careful to balance the costs versus benefits of our regulations-we must maintain the integrity of our markets so that investors have confidence that they will be treated fairly, but we also must

104 See, e.g., Tamar Frankel, The Ninth Annual Abraham L. Pomerantz Lecture: Regulation and Investors' Trust in the Securities Market, 68 BROOK. L. REV. 439, 443-44 (2002).

${ }^{105} \mathrm{Id}$.

106 Michael D. Bordo, The Globalization of International Financial Markets:

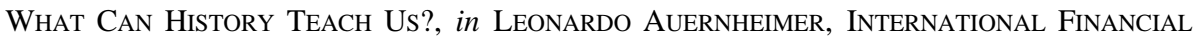
MARKets: The Challenge of Globalization 30 (2003).

${ }^{107}$ Madoff's Victim List, WALL ST. J., Mar. 6, 2009, available at http://s.wsj.net/public/ resources/documents/st_madoff_victims_20081215.html.

${ }^{108}$ See, e.g., Frankel, supra note 104, at 442. 
not price those very investors out of our markets through burdensome regulations. ${ }^{109}$

The work of U.S. regulators is further complicated by the fact that the SEC is, in the words of one commentator, "overworked and understaffed."110 Therefore, the SEC is not able to proactively regulate corporate behavior so as to deter fraudulent activity, and, instead, must rely on private enforcement mechanisms.

In the aftermath of the sub-prime mortgage crisis and the revelation of recent securities fraud scandals, a consensus has emerged that the SEC and other regulators have failed to properly maintain the balance between the costs and benefits of its regulations. The resulting loss of confidence in financial regulators extends internationally as well. In early 2009, the United Nations Conference on Trade and Development ("UNCTAD") issued a report on the global economic crisis citing a number of "systemic factors" that contributed to the crisis, including "the fullfledged deregulation of financial markets and the increased sophistication of speculation techniques and financial engineering."111

On the flip side, an open-ended approach creates uncertainty for issuers regarding potential liability under U.S. antifraud rules. This may have a chilling effect on valuable economic activity in the United States, as foreign companies limit their business within the United States in order to avoid the risk of having to defend against costly litigation in U.S. courts. ${ }^{112}$ For example, if the Morrison case had came out the other way, it could have potentially discourage foreign companies from investing in U.S. subsidiaries. Furthermore, as multiple countries can often claim a legitimate regulatory interest in regulating the same conduct, the cost of multiple regulations becomes burdensome to businesses. Concurrent jurisdiction may not always be a problem, but when multiple countries are able to assert their regulatory jurisdiction over conduct because of effects on their citizens, and one or more other countries are also able to apply their laws and regulations because of conduct within their borders, the cost of compliance with all these rules can become prohibitive. For example, in a recent alleged fraud by the French media company Vivendi Universal, S.A., French regulatory authorities carried out a criminal investigation into the scandal. ${ }^{113}$ At the same time, the company was sued in U.S. federal court under Rule

109 Paul S. Atkins, Commissioner, Securities Exchange Commission, Speech in Paris, France: The SEC's Evolving Regulatory Role in an Increasingly Integrated World Economy (May 16, 2006), http://www.sec.gov/news/speech/2006/spch051506psa.htm.

${ }^{110}$ Buschkin, supra note 22, at 1592.

111 U.N. Conf. on Trade and Dev. [UNCTAD] Report, Secretariat Task Force on Systematic and Economic Cooperation, The Global Economic Crisis: Systematic Failures and Multilateral Remedies, ix, U.N. Doc UNCAD/GDS/2009/1 (2009) (foreward by Supachai Panitchpakdi Secretary-General of UNCTAD), available at http://www.unctad.org/en/docs/ gds20091_en.pdf.

${ }^{112}$ See generally Comm. on Capital Mkts. Regulation, Interim Report of the Committee on Capital Markets Regulation (2006), available at http://capmktsreg.org/pdfs/11.30Committee_ Interim_ReportREV2.pdf (discussing the costs of the "litigation burden” in U.S. markets).

113 Both the company and its CEO were fined for violations by the French financial regulators (300,000 and 500,000 euros, respectively). AUTORITÉ DES MARCHÉs FINANCIÈRES, DÉCision de SANCTION À L'ÉGARD DE M. JEAN-Marie Messier, DE M. Guillaume Hannezo 
10b-5 by both European and U.S. investors. It is also becoming increasingly costly for regulators and judicial systems to enforce the law, as more and more transactions can implicate a country's regulatory system on the basis of tenuous contacts with that country. ${ }^{114}$

In addition to potential over-regulation, too broad of an extraterritorial application of the U.S. antifraud rules could result in jurisdictional conflict with other countries seeking to regulate the same transaction. Because of variations in the intensity of enforcement and the remedies available, investors may forum-shop to find the most favorable forum in which to bring their suit. ${ }^{115}$ Countries that have made the regulatory judgment to provide less investor protection could, therefore, have their legislative judgment thwarted. ${ }^{116}$ In other contexts, such as antitrust, broad assertions of extraterritorial application of U.S. laws has raised diplomatic protests. ${ }^{117}$ While the extraterritorial application of U.S. antifraud rules has not yet caused significant clashes with other countries, some commentators fear that it is only a matter of time. ${ }^{118}$

\section{StRiking the Right Balance: Prospects and OpPortunities For ReForm}

Given the recent increase in foreign-cubed claims in U.S. courts, and cases such as Morrison, the time is ripe to re-examine the conduct test and the problems it presents. There is considerable fragmentation among courts on how to apply the conduct test to claims of transnational securities fraud, and courts have struggled to find the proper balance among the competing interests at issue. ${ }^{119}$ However, in spite of the imperfections of the current approach taken by courts to address the question of extraterritoriality, reform is a thorny issue. Although broad assertions of extraterritoriality risk cause jurisdictional conflict and overregulation, ${ }^{120}$ too narrow of an approach to extraterritoriality will make it easier for opportunistic issuers to structure transactions specifically to avoid application of U.S. antifraud rules, and may result in under-regulation.

ET DE LA SOCiÉTÉ Vivendi Universal [FinAnCial Markets Authority, SANCTION Decision In Respect of Mr. Jean-Marie Messier, Mr. Guillaume Hannezo and the COMPany VIVENDI UNIVERSAL] (Nov. 3, 2004), available at http://www.amf-france.org/documents /general/5649_1.pdf.

114 This is particularly poignant in the United States in the context of the foreign-cubed cases, where increasingly tenuous links to the United States lead to often-costly litigation in U.S. courts. See Grant \& Zilka, supra, note 28; Brief of SEC, supra note 29; PriceWaterhouse Coopers, supra note 30.

${ }^{115}$ Urquhart, supra note 10, at 474.

${ }^{116} \mathrm{Id}$.

117 See, e.g., Austen Parrish, The Effects Test: Extraterritoriality's Fifth Business, 61 VAND. L. REV. 1455, 1473 n.99 (2008).

${ }^{118}$ See, e.g., Buxbaum, supra note 2, at 17.

${ }^{119} I d$. at $24-25$.

${ }^{120}$ See, e.g., Guzman, New Foundations, supra note 34, at 906; Stephen J. Choi \& Andrew T. Guzman, The Dangerous Extraterritoriality of American Securities Law, 17 Nw. J. INT'L L. \& Bus. 207, 216-17 (1996). 


\section{A. A Market-Based Approach?}

To address the problems presented by transnational securities fraud, a number of commentators have suggested limiting the extraterritorial reach of securities laws. Apart from the bright-line rule urged by the defendants in Morrison, some legal scholars have argued that there should be an exchange-based choice-of-law rule. In other words, if foreign investors transacted in foreign securities on a non-U.S. exchange, they would be barred from bringing a Rule 10b-5 claim in U.S. courts against the foreign issuer. ${ }^{121}$ This approach focuses on the effects of an alleged fraud, and would result in discarding the conduct test altogether. It takes the view that governments should only be concerned about regulating conduct that has effects on persons within their jurisdiction. ${ }^{122}$ The best way to maximize global welfare, on this view, is to rely on the securities market to select the optimal level of regulation. ${ }^{123}$

Thus, an exchange-based rule would provide a number of benefits. First, it would provide issuers with valuable certainty as to the applicable law. Such certainty would reduce the costs associated with offering securities and, therefore, allow the securities to be sold at a better price to investors. Second, this approach would theoretically lead to a socially optimal level of regulation. ${ }^{124}$ If issuers choose to offer their securities on exchanges where investors perceive they would not receive adequate protection, investors will offer less for the securities than the issuer could obtain on an exchange associated with more investor-friendly rules. Conversely, under regimes where the marginal cost of additional regulations would outweigh the marginal benefits of the higher price investors might be willing to pay, issuers will not choose to sell there. ${ }^{125}$

In the context of fraud in modern securities markets, there are three key problems with this approach. The first problem is that this approach ignores the interconnectedness of the financial markets and the resulting interest of governments in punishing fraud regardless of who is directly harmed. Fraud in one place can have a chilling effect on markets worldwide, and even investors and markets not directly affected by a fraud can be harmed indirectly by fraudulent activity elsewhere. ${ }^{126}$ This means that the U.S. and other countries have a strong interest in deterring fraud regardless of where the effects are felt. Excluding foreign claimants from bringing securities fraud lawsuits in the United States or from participating in class actions in the United States undermines the deterrent effect of the private cause of action under

${ }^{121}$ Choi \& Guzman, supra note 120, at 222.

122 See Guzman, New Foundations, supra note 34, at 894.

${ }^{123}$ See id.

124 See, e.g., Merritt B. Fox, Retaining Mandatory Securities Disclosure: Why Issuer Choice is Not Investor Empowerment, 85 VA. L. REV. 1335, 1337-8 (1999).

${ }^{125}$ Guzman, New Foundations, supra note 34, at 914.

${ }^{126}$ See IOSCO, Financial Fraud, supra note 7, at ii (noting that the concerns raised by financial scandals involving large, publicly-traded companies are "truly global in nature"). 
Rule 10b-5. ${ }^{127}$ The benefits of the private cause of action, and the class action lawsuit in particular, are not available in most other countries that "lack private procedural instruments which can generate rigorous substantive control."128

A second problem with the market-based approach to fraud regulation is that it ignores other factors influencing the choice of law, or, as here, the selection of a market. In practice there are many factors besides antifraud protections that dictate where people invest and where issuers choose to sell their securities, including tax considerations, expertise of regulators, reporting requirements, and even simple geography. All other things being equal, the law and economics approach to antifraud regulation might be a good one, but unfortunately, all other things are not equal. ${ }^{129}$ Therefore, market selection may not lead to the optimal level of antifraud protection. A market-based approach may in fact lead to a regulatory "race to the bottom." 130 Related to this is the law-and-economics assumption of the rational investor, which holds that investors price the potential for fraud into the securities they purchase. An alternative model of investor behavior, the so-called "trusting investor" model, ${ }^{131}$ argues that investors "are willing to lose fair and square but not to be taken by fraud." 132 After they are defrauded, investors lose trust in securities markets, leading to price declines and potentially prolonging a bear market. ${ }^{133}$ While it is unclear which view of investor behavior more closely corresponds with reality, there is at least some evidence that a significant number of investors better fit the "trusting investor" model. ${ }^{134}$ This evidence against the rational investor model, combined with the potential for a regulatory race-to-the-bottom, cautions against letting the markets decide the appropriate level of antifraud regulation.

Third, for the market-based approach to act as a stand-in for U.S. regulatory law when it comes to protecting defrauded U.S. investors, one must assume that all other countries with a stock exchange have an adequate antifraud enforcement regime. Such an assumption may be true with respect to some countries but certainly not all of them. Even financially developed countries such as Germany have recently been reexamining their securities enforcement system following large corporate

\footnotetext{
${ }^{127}$ See Ilana T. Buschkin, The Viability of Class Action Lawsuits in a Globalized Economy - Permitting Foreign Claimants to be Members of Class Action Lawsuits in the U.S. Federal Courts, 90 CORNELl L. REV. 1563, 1588 (2005).

${ }^{128}$ Id. (citing Richard B. Cappalli \& Claudio Consolo, Class Actions for Continental Europe? A Preliminary Inquiry, 6. TEMP. INT’L \& COMP. L.J. 217, 267-8 (1992)).

${ }^{129}$ See Paul B. Stephan III, The Political Economy of Choice of Law, 90 GEO. L.J. 957, 959 (2002).

${ }^{130}$ The race-to-the-bottom versus race-to-the-top debate has recurred throughout corporate legal scholarship. See, e.g., Lucian A. Bebchuk \& Alma Cohen, Firms' Decisions Where to Incorporate, 46 J.L. ECON. 383 (2003).

${ }^{131}$ See generally Lynn A. Stout, The Ninth Annual Abraham L Pomerantz Lecture: The Investor Confidence Game, 68 BROOK. L. REV. 407, 415-20 (2002).

${ }^{132}$ Frankel, supra note 104, at 443 n.17.

${ }^{133}$ Stout, supra note 131, at 436.

${ }^{134}$ See generally, id.
} 
scandals. ${ }^{135}$ The SEC has argued against such an approach, fearing it would let too much fraud slip through the cracks. ${ }^{136}$

A modification of the exchange-based rule that potentially addresses the last of these problems, the one involving inadequate enforcement in other countries, has been proposed by Professors Choi and Silberman. ${ }^{137}$ They have argued for an exchange-based jurisdictional presumption, which would be rebuttable ex-ante by a determination by the SEC that certain countries lack effective antifraud rules and, therefore, U.S. law should be applied to claims of investors trading in those certain countries. ${ }^{138}$ This proposal is effectively a market-based approach, giving certainty as to the applicable law, at least for transactions taking place on a market that the SEC considers to be adequately regulated. It would also address the third of the criticisms of a pure market-based approach outlined above, that some countries may not have an adequate antifraud enforcement regime. As such, this market-based presumption approach would be a better solution than the pure exchange-based rule. However, it would not address the other two problems with an exchange-based rule discussed above. In addition, the SEC "blacklist” contemplated by this proposal may be problematic, as it is unlikely in the current climate that the SEC would consider the antifraud enforcement systems of other countries up to par.

A final point with regards to any proposed reform aimed at limiting extraterritorial application of U.S. antifraud rules is that narrowing the extraterritorial scope of U.S. law would not address the problem of jurisdictional conflict caused by transnational securities fraud generally. Although it would limit criticisms by other countries of the United States' approach to extraterritorial application of its laws, the overall problem of a transaction being subject to multiple regulatory systems would not go away. ${ }^{139}$ Other actors around the world are catching on to the fact that there may be something to be gained in helping allegedly defrauded investors seek redress. ${ }^{140}$ Even if the U.S. cedes its position as the most plaintiff-friendly forum for adjudicating transnational securities fraud claims, it is only a matter of time before another country's system steps in to fill that role. ${ }^{141}$

While there is merit to the argument that the United States cannot police the world for securities fraud, ${ }^{142}$ there is a clear U.S. interest in allowing at least some foreign claimants to bring suit in U.S. courts and/or to participate in class actions. As one commentator points out, if multinational corporations believe they can

135 See Astrid Stadler, A Test Case in Germany: 16,000 Private Investors vs. Deutsche Telekom, Academy of European Law (Mar. 3, 2009) (discussing recent German reforms to its securities laws act aimed at coping with mass litigation in German courts).

${ }^{136}$ SEC Brief, supra note 29.

${ }^{137}$ Choi \& Silberman, supra note 38.

${ }^{138} I d$. at 465 .

${ }^{139}$ See Urquhart, supra note 10, at 478.

${ }^{140}$ See, e.g., Redwood, supra note 23.

${ }^{141}$ See Urquhart, supra note 10, at 478.

142 See Morrison, 547 F.3d at 175 (asserting that "we are an American court, not the world's court”). 
engage in fraud with little consequence over large portions of the globe, they will either:

[a]dopt a two-tiered system, in which U.S. customers are treated differently from foreign customers, or corporations continue to injure both U.S. and foreign purchasers alike, calculating that profits gained from abroad more than make up for the court fees and damages that must be paid out to U.S. purchasers. ${ }^{143}$

And, the United States has an interest in preventing both of these scenarios to protect its securities markets and investors. The United States has long recognized that allowing fraudulent activity within its borders, even if the harm is only to foreigners, is contrary to its public policy. ${ }^{144}$

\section{B. The Case for a Multilateral Resolution}

Another potential solution to the jurisdictional problems raised by transnational securities fraud would be a multilateral negotiated solution. ${ }^{145}$ As noted in a recent report by the International Bar Association ("IBA"), "[t]here is a profound consensus among regulators, academics, financial institutions and others that the regulatory framework of the international financial markets needs to undergo a fundamental change to address the diminished influence of national and regional securities regulators over cross-border financial activities." ${ }^{146}$ This consensus applies to all areas of financial regulation. ${ }^{147}$ However, it is particularly present in the context of deterring and punishing securities fraud, which is necessary to maintain the stability and prosperity in the capital markets.

Transnational securities fraud provides an ideal backdrop for international cooperation. First of all, the problems caused by securities fraud-lack of investor confidence, reduced liquidity in the markets, and depressed prices-are no longer contained to one country or region but will affect capital markets throughout the world. ${ }^{148}$ Furthermore, most countries with a securities market have regulations aimed at discouraging financial fraud. ${ }^{149}$ While the prohibitions on fraud vary in

143 Buschkin, supra note 22, at 1589.

144 See, e.g., Itoba Ltd. v. LEP Group PLC, 54 F.3d 118, 121-2 (2d Cir. 1995); Urquhart, supra note 10 , at 478, n. 47 .

145 There is some consensus among scholars that international cooperation would be the optimal approach to the problem. See, e.g., Buxbaum, supra note 2, at 68; Guzman, New Foundations, supra note 34, at 935; Urquhart, supra note 10 at 478 . However, there is little, if any, agreement as to the form that a multilateral solution should take.

${ }^{146}$ INTERNATIONAL BAR ASSOCIATION, REPORT OF THE TASK FORCE ON EXTRATERRITORIAL JURISDICTION 273 (2009) (hereinafter IBA Report).

${ }^{147}$ See id.

${ }^{148}$ IOSCO, Financial Fraud, supra note 7, at ii; see also, Ana Carvajal \& Jennifer Elliott, The Challenge of Enforcement in Securities Markets: Mission Impossible? 6-11 (International Monetary Fund, Working Paper WP/09/168, 2009).

149 Institute of Internal Auditors, American Institute of Certified Public Accountants, and Association of Certified Fraud Examiners, Managing the Business 
form, in substance they all aim to eradicate essentially the same behavior. ${ }^{150}$ Similarly, all countries with an active securities market have an interest in reducing the inefficiencies created by overregulation and jurisdictional conflict. In the wake of the recent financial crisis, there is an even greater consensus among countries that cooperation and reform are needed in the area of financial regulation. ${ }^{151}$ Therefore, the current climate presents a significant opportunity for the relevant actors to pursue a multilateral solution to the problems presented by transnational securities fraud.

So far, the main efforts at cooperation and coordination in enforcing antifraud rules have focused on implementing minimum international standards and providing for cooperation in cross-border enforcement. ${ }^{152}$ The International Organization of Securities Commissions ("IOSCO") has been working for some time on promoting cooperation among the world's securities regulators to create guidelines and facilitate cross-border enforcement. ${ }^{153}$ However, IOSCO has had only limited success in furthering the much needed rapprochement between regulatory systems. ${ }^{154}$

Over the years, IOSCO's role has mainly consisted of information sharing and collecting, and making recommendations of non-binding guidelines for regulators. ${ }^{155}$ In 2002, the organization adopted a Multilateral Memorandum of Understanding ("MMOU") "designed to facilitate cross-border enforcement and exchange of information among the international community of securities regulators." ${ }^{\text {"156 }}$ The MMOU sets forth a framework for information sharing between members, including the type of information obtainable, procedures for requesting such information, and authorized uses for the information. ${ }^{157}$ As of this writing, the MMOU has sixty-four signatories from among the world's securities regulators, including the SEC and the U.S. Commodity Futures Trading Commission. ${ }^{158}$ However, the MMOU is non-

Risk OF FrAUD: A PRACTICAL GUIDE 11 (2008), http://www.acfe.com/documents/managingbusiness-risk.pdf.

150 For example, compare Rule 10b-5 with other antifraud regulations: Directive 2003/6/EC of the European Parliament and the Council of 28 January 2003 on insider dealing and market manipulation (market abuse), Article 1(2), OJ L 96/16; Trade Practices Act, 1974 c. 52 (Austl.); Sanzhu Zhu, Civil Litigation Arising from False Statements on China's Securities Market, 31 N.C. J. INT’L L. \& COM. REG. 377, 378-79 (2005).

151 This has been a major topic of discussion among world leaders at the Group of 20 talks. Matt Spetalnick, Financial Regulation Rises to Top of G20 Agenda, ReUTERS, Sept. 19, 2009, http://www.reuters.com/article/GCA-GCA-G20/idUSTRE58G34Z20090919.

${ }^{152}$ IOSCO, Financial Fraud, supra note 7, at iii.

153 IOSCO Historical Background, http://www.iosco.org/about/index.cfm?section=history (last visited Apr. 20, 2010).

${ }^{154}$ See Urquhart, supra note 10, at 477.

${ }^{155}$ See General Information on IOSCO, http://www.iosco.org/about/ (last visited Apr. 20, 2010).

${ }^{156}$ OICV-IOSCO, IOSCO Historical Background, http://www.iosco.org/about/index.cfm? section=history (last visited Apr. 16, 2010).

${ }^{157}$ Carvajal \& Elliot, supra note 148, at 23.

158 See OICV-OISCO, List of Signatories to the IOSCO Multilateral Memorandum of Understanding Concerning Consultation and Cooperation and the Exchange of Information, http://www.iosco.org/library/index.cfm?section=mou_siglist (last visited Apr. 16, 2010). 
binding, and significant legal barriers to its implementation still exist in many countries. ${ }^{159}$ In addition, while information sharing is helpful, it does not solve the problems that arise when multiple countries seek to apply their laws to the same activity. Nor does it solve the problems of inadequate enforcement. Recent IOSCO assessment reports have found that many countries "face significant challenges in implementing credible and effective enforcement programs." 160 Given the limited success of IOSCO and other voluntary efforts thus far, as well as the urgency of addressing the issues raised by transnational securities fraud, it is clear that another approach is in order.

Recognizing that abolishing national regulations in favor of a comprehensive set of international regulations is neither very feasible nor the most favorable approach, the IBA Report calls for synchronization of existing national and regional regulations. ${ }^{161}$ Such synchronization can come about through convergence or standardization, exemption, or recognition. ${ }^{162}$ These approaches, or some combination thereof, are already being employed by some countries. For example, harmonization of minimum standards in combination with mutual recognition lies at the heart of the European Union ("EU") "passport" system of securities regulation between EU member states. ${ }^{163}$ Similarly, many countries are entering into mutual recognition agreements such as the U.S.-Australia Memorandum of Understanding Concerning Consultation, Cooperation and the Exchange of Information Related to the Enforcement of Securities Laws ("U.S.-Australia MOU”). ${ }^{164}$ Some combination of these same approaches—-harmonization, exemption, and recognition—could help resolve the problems raised by transnational securities fraud.

Advocates of an exchange-based choice of law rule favor the market-based approach because it would avoid jurisdictional conflict and reduce costly inefficiencies. ${ }^{165}$ In a similar vein, the IBA urges governments to "agree upon a framework that provides for one jurisdiction to be the appropriate jurisdiction in which enforcement action will be taken in relation to any particular misconduct."166 The aim would be to create a form of cross-jurisdictional rule against double jeopardy, ${ }^{167}$ thus avoiding conflicts between jurisdictions who disagree as to the proper form or intensity of regulation of certain conduct, and limiting costs associated with the inefficiencies caused by overregulation. However, rather than

${ }^{159}$ Carvajal \& Elliot, surpa note 148, at 23.

${ }^{160} \mathrm{Id}$. at 34 (citing findings of IOSCO assessments carried out in 80 jurisdictions).

${ }^{161}$ IBA Report, supra note 146, at 279.

${ }^{162} I d$.

${ }^{163}$ Id. at $279-80$.

${ }^{164}$ Memorandum of Understanding Concerning Consultation, Cooperation and the Exch. of Info. Related to Mkt. Oversight and the Supervision of Fin. Servs. Firms, Aug. 25, 2008, U.S-Austl., available at http://www.sec.gov/about/offices/oia/oia_mututal_recognition/ australia/supervisory_mou.pdf.

${ }^{165}$ See Guzman, New Foundations, supra note 34, at 908.

${ }^{166}$ IBA Report, supra note 146, at 301.

${ }^{167} \mathrm{Id}$. 
U.S. courts adopting a unilateral exchange-based choice of law rule, a similar result could be achieved while still ensuring adequate protection of investors and the markets, through a multilateral mutual recognition system.

First, some level of harmonization of the standard for what constitutes prohibited fraud may be necessary. Then, countries could adopt a mutual recognition system similar to that in place between EU member states. Mutual recognition essentially requires "that each country recognize the adequacy of the rules and regulations of another country," thus permitting a regulated entity to do business in both jurisdictions. ${ }^{168}$ A similar multilateral agreement could be negotiated between a broader number of jurisdictions, under which the parties would recognize the adequacy of each other's antifraud regimes. Rather than simply providing minimum standards, such as the current IOSCO principles, ${ }^{169}$ the mutual recognition system would provide a stronger incentive for countries with inadequate enforcement systems to strengthen their regulatory regimes. Some countries would undoubtedly need to update their antifraud rules or enforcement systems before other nations would be willing to admit them to the mutual recognition framework. Because of the obvious benefit to businesses of such an arrangement, national governments would have a strong incentive to ensure their regulatory systems were up to par and to undertake any necessary reforms. IOSCO could perhaps serve as a central overseer of the system, ensuring that a country's regulatory system met certain minimum standards in terms of substance and enforcement capability before it would be admitted to the mutual recognition agreement. The arrangement should also include technical and capacity building assistance for emerging markets to strengthen their regulatory capability. ${ }^{170}$

A choice-of-law framework would accompany the mutual recognition system for determining which nation's law would apply to a particular transaction. The framework would be applicable both in the context of a public enforcement action and in private lawsuits. Determining the proper jurisdiction could be done in a number of ways. The agreement could provide that the primary trading market of a company's securities would be the proper jurisdiction. ${ }^{171}$ Alternatively, the jurisdiction of incorporation of the issuer could be the presumptive jurisdiction for enforcement. There is some precedent on which to base such a jurisdictional arrangement. For example, the Hague Conference on Private International Law has overseen the drafting of a number of conventions that are jurisdictional in nature. The far-reaching Draft Convention on Jurisdiction and Foreign Judgments in Civil and Commercial Matters is one such framework, though negotiations on this broad

${ }^{168}$ Eric J. Pan, A European Solution to the Regulation of Cross-Border Markets, 2 BROOK. J. CORP. Fin. \& COM. L. 133, 140 (2007).

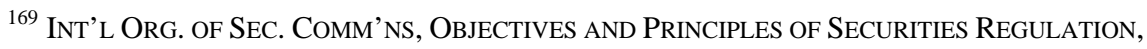
i-iii (1998), http://www.iosco.org/library/pubdocs/pdf/IOSCOPD82.pdf (setting forth the thirty principles of securities regulation).

${ }^{170}$ Carvajal \& Elliot, supra note 148, at 35 (urging that capacity building assistance should be made a priority).

${ }^{171}$ The definition of a primary trading market could perhaps be drawn from the definition contained in the U.S. securities laws where it is used in connection with registration exemptions for certain foreign securities. See 17 C.F.R. § 240.12g3-2(b)(1), n.1 (2010). 
agreement have stalled, and parties have struggled to reach consensus. ${ }^{172}$ Similarly, the Hague Convention on the Law Applicable to Certain Rights in Respect of Securities Held with an Intermediary could be used as a model for the jurisdictional agreement. ${ }^{173}$

Of course, adopting a system such as the one outlined above would not be without difficulty. Governments will undoubtedly be reluctant to participate in an agreement which they perceive as forcing them to cede regulatory authority over securities fraud activity. To mitigate this concern, rather than creating a strict rule under which only one country would have jurisdiction over a particular instance of fraud, the agreement could perhaps contemplate a hierarchy of regulatory authority. Under such a hierarchy one state would have presumptive priority over particular conduct. Further, under certain circumstances that would be enumerated in the agreement another country could, however, apply its law to the activity instead. Such an approach is not unprecedented in international law. For example, under the UN Convention for the Recognition and Enforcement of Foreign Arbitral Awards, arguably one of the most successful international treaties dealing with jurisdictional considerations, authority to set aside an arbitral award is only granted to the courts of the country where the award was rendered, except in certain enumerated circumstances. ${ }^{174}$

In addition to the standardization-and-mutual-recognition approach outlined above, bilateral and multilateral cooperation agreements could be a complementary tool for furthering a multilateral solution to the problem of transnational securities fraud. Cooperation agreements, including the U.S.-Australia MOU mentioned above, and others such as a Multilateral Memorandum on the Exchange of Information and on the Surveillance of Securities Activities between the members of the Forum of European Securities Commissions, ${ }^{175}$ are already in place. Though, they vary in the level of cooperation promised and their enforceability. ${ }^{176}$ These

172 See, e.g., William E. O’Brien, Jr., The Hague Convention on Jurisdiction and Judgments: The Way Forward, 66 MoD. L. REV. 491, 492 (2003) (Because of the expansive scope of the Jurisdiction and Judgments Convention, negotiations came to a standstill over a number of significant differences between the approach to jurisdictional rules, in particular between the United States and the European Union.).

${ }^{173}$ Convention on the Law Applicable to Certain Rights in Respect of Securities Held with an Intermediary, July 5, 2006. This Convention has had arguably a bit more success than the Judgments Convention, having been ratified by both Switzerland and the United States. See Status Table, Convention of 5 July 2006 on the Law Applicable to Certain Rights in Respect of Securities held with an Intermediary, available at http://www.hcch.net/index_en. php?act=conventions.status\&cid=72.

${ }^{174}$ United Nations Convention for the Recognition and Enforcement of Foreign Arbitral Awards, June 10, 1958, 9 U.S.C. § 201, 21 U.S.T. 2517 (hereinafter New York Convention); see also, William W. Park, The International Currency of Arbitral Awards, Practicing Law Institute, 770 PRAC. L. INST. 359, 390 (2008) (describing a hierarchy of jurisdictions under the New York Convention).

175 Press Release, Signature of an European Memorandum of Understanding on the Surveillance of Securities Activities and the Creation of "FESCOPOL", (Feb. 1, 1999) available at http://www.esma.europa.eu/popup2.php?id=276.

${ }^{176}$ Maritime Delimitation and Territorial Questions (Qatar v. Bahrain), 1994 I.C.J. 112, 121-22 (July 1) (MOUs were found to be legally binding international agreements even 
agreements help regulators to collect information they would not otherwise be able to obtain in some instances of transnational fraud, easing the way for enforcement.

The multilateral solution proposed above is not the only way in which countries could work together to address the problems posed by the increasing instance of transnational securities fraud. However, governments should prioritize international cooperation in this arena. Recent events in the global financial markets, as well as contentious cases such as Morrison that raise important jurisdictional considerations in adjudicating transnational securities fraud claims, present an opportunity for catalyzing cooperation that should be seized. Any multilateral solution should address both increased cooperation in terms of information sharing and enforcement, but negotiators should also consider a framework that would limit the instances where multiple nations would seek to regulate the same activity, ${ }^{177}$ while still ensuring that transnational frauds do not go unpunished.

\section{CONCLUSION}

Transnational securities fraud has increased the costs and complicated national securities regulator's enforcement work. It also creates potential for underenforcement, as no one country may have sufficient incentives to enforce its antifraud rules against an international violator. This situation underscores the need for a private enforcement mechanism for investors to seek redress, preferably all together and in one forum in order to reduce inefficiencies. Uncertainty as to the applicable law and potential overregulation when multiple jurisdictions seek to impose penalties for the same fraudulent activity cause costly inefficiencies in the market. It is also unsustainable for the United States to act as the international policeman for securities fraud. In addition, an overly broad extraterritorial application of national regulatory law may cause jurisdictional conflict with other countries. A market-based rule or presumption, as suggested by some commentators, would help resolve the problems of overregulation and jurisdictional conflict. However, such a rule could result in under-regulation, which comes with its own costs in terms of reduced investor confidence in the markets. Ideally, a multilateral solution should be negotiated that would encourage countries to meet certain minimum standards in terms of substance and enforcement of securities antifraud rules, while at the same time providing a jurisdictional or choice-of-law agreement to determine a primary enforcement jurisdiction.

The Morrison case has drawn renewed attention to the U.S. courts' approach to dealing with transnational securities fraud, and underscores the need for reform. ${ }^{178}$ The dispute on the extraterritorial application of U.S. securities antifraud rules

though Bahrain requires legislative approval and MOUs were not approved by the legislature. MOU status of enforceability is not affected by non-registration or late-registration. Therefore, Bahrain, was precluded from arguing that Qatar did not think MOU was an international agreement because they did not register it until six months after the signing.).

${ }^{177}$ IBA Report, supra note 146, at 301.

${ }^{178}$ See, e.g., Choi \& Silberman, supra note 38, at 492 ("[T] on assumptions on how foreign investors and others abroad form views on fraud responsibility, the amount and importantly the qualitative type of conduct that must occur in the United States to trigger the conduct test is uncertain. Because such assumptions lack empirical support and are simply ad hoc on the part of specific courts, litigants face difficulty in predicting the application of the conduct test.”). 
among courts, academics, and other actors should motivate the U.S. government to initiate multilateral discussion of the issue. Though, a multilateral negotiated solution will take some time to achieve. The Supreme Court granted certiorari in the Morrison case. ${ }^{179}$ As this author expected, the Supreme Court affirmed the Second Circuit's decision. ${ }^{180}$ The Supreme Court grounded its decision on the fact that the §10(b) did not apply extraterritorily and thus only applied to securities on domestic exchanges. ${ }^{181}$ Accordingly, there was no claim as the securities involved were no listed on a domestic exchange. ${ }^{182}$ As discussed in Part I(b) supra, the private enforcement mechanism in the United States is important to ensuring the securities laws are adequately enforced. ${ }^{183}$ In addition, there are a number of other considerations that weigh in favor of preserving a flexible approach to the question of extraterritorial application of the antifraud rules.

Some commentators have argued that courts should adopt a presumption in favor of extraterritoriality, urging that "reasonable" extraterritorial assertions of U.S. regulatory law will encourage international cooperation and lead to more bilateral and multilateral agreements to resolve conflicts and improve global regulation. ${ }^{184}$ It is difficult to prove that U.S. courts' approach to the extraterritorial application of U.S. securities laws has caused the movement towards increased bilateral cooperation. However, it is clear that bilateral cooperation has not been stunted. There has also been greater multilateral cooperation in recent years, for example, in the form of the multilateral memorandum of understanding adopted by the

179 At the time of writing, the Supreme Court was set to hear oral arguments in March 2010, and a decision was expected by July 2010.

${ }^{180}$ Morrison v. Nat'l Austl. Bank Ltd., 130 S.Ct 2869 (U.S. 2010).

${ }^{181} \mathrm{Id}$. at 2883-4. "International and foreign organizations . . complain of the interference with foreign securities regulation that application of $\S 10(\mathrm{~b})$ abroad would produce, and urge the adoption of a clear test that will avoid that consequence. The transactional test we have adopted--whether the purchase or sale is made in the United States, or involves a security listed on a domestic exchange--meets that requirement." Id. at 2886.

${ }^{182}$ Perhaps in recognition of the considerations that weigh in favor of a flexible approach to the extraterritorial application of the U.S. securities antifraud rules, the U.S. House of Representatives passed a bill in December 2009 that would codify the court's current approach to apply the antifraud rules extraterritorially. However, the language in the bill is not the same as that used by the Second Circuit's conduct test, and would simply require that "significant steps" towards the alleged fraud be taken within the United States, triggering fears among some that the bill would make it easier for foreign plaintiffs to sue in U.S. courts. Tom Braithwaite \& Helen Thomas, Fears Over Tough U.S. Antifraud Legislation, Fin. Times, Nov. 22, 2009, available at http://www.ft.com/cms/s/0/58355e8e-d7a0-11de-b578-00144feabdc0 .html. The bill is now up for consideration before the Senate, but it is unclear when the Senate may address this, and it is of course possible that the bill passed by the house will face substantial scrutiny and amendments by the Senate. Wall Street Reform and Consumer Protection Bill of 2009, H.R. 4173, $111^{\text {th }}$ Cong. (2009).

${ }^{183}$ See Isaacharoff, supra note 21.

184 Weintraub, supra note 45, at 1817. Reasonable extraterritorial assertions include application of U.S. laws to conduct causing harm abroad, in the context of securities fraud, and also to conduct abroad that has "direct, substantial, and reasonably foreseeable effects" in the United States. Id. at 1825 n.158. 
International Organization of Securities Commissions in 2002. ${ }^{185}$ Such activity has coincided with the increasing internationalization of the world's financial markets as well as increased incidence of securities fraud claims in U.S. courts by foreign plaintiffs.

A presumption in favor of the extraterritorial application of U.S. antifraud rules, of course, is victim to the various criticisms that have been made by proponents of a market-based rule. It is more likely to lead to overregulation, thus creating economic inefficiencies. In addition, broader extraterritorial application will more likely lead to jurisdictional conflict. However, the criticisms of this approach may be outweighed by its benefits. There is little evidence that fear of extraterritorial assertions of the antifraud rules have caused foreign companies to avoid conducting business in the United States. ${ }^{186}$ Although U.S. equity markets may no longer be the markets of choice for the world's corporations, there are many factors that have contributed to this, and the blame cannot all be laid on overregulation or shareholder lawsuits. ${ }^{187}$

Further, the problem of jurisdictional conflict is less acute in the realm of securities law than in other areas such as antitrust. ${ }^{188}$ As noted above, securities fraud is almost universally prohibited. The substance of the law is also fairly similar across the world. ${ }^{189}$ While procedural and enforcement mechanisms differ, private enforcement in general is becoming more universally accepted. For example, China has recently opened the way for civil disputes relating to securities fraud. ${ }^{190}$ Even the French government has recently stated that it is not opposed to the idea of class actions cases in France for investor redress, though no reform to this effect has yet made much headway. ${ }^{191}$ All this signals increasing acceptance of the U.S. approach

${ }^{185}$ IOSCO.org, General Information on IOSCO, Historical Background, http://www.iosco. org/about/index.cfm?section=history (last visited April 27, 2010).

${ }^{186}$ For a contrary view, see Comm. on Capital Markets Regulation, supra note 112.

${ }^{187}$ See generally Eric Pan, Why the World No Longer Puts Its Stock in Us (Benjamin N. Cardozo School of Law, Working Paper No. 176, 2006), available at http://ssrn.com/ abstract=951705. Factors that have arguably had a greater effect on decreased activity by foreign companies in the United States include the burdens of the Sarbanes-Oxley Act, the fact that foreign companies can access U.S. investors without registering in the United States, thereby avoiding the added costs of SEC review, and the increasing competitiveness of foreign markets. Id. at 2 .

188 See, e.g., Restatement (Third) of Foreign Relations § 416 (1987). This may be in part because of the treble damages penalties available in private litigation of antitrust violations. In securities cases, damages are only compensatory.

189 Compare 17 C.F.R. §240.10b-5 (2009) with Trade Practices Act. 1974, c 52 (Austl.) (prohibiting a corporation from engaging in conduct in trade or commerce that "is misleading or deceptive or is likely to mislead or deceive).

190 People's Daily Online, China Offers Stronger Legal Support to Crackdown on Securities Fraud, Jan. 9, 2003 (English Edition) (Jan. 9, 2003), http://english.peopledaily.com .cn/200301/09/eng20030109_109850.shtml.

${ }^{191}$ See generally Olivier Cavézian, et. al., Class Actions in Europe: Reality or Myth? The Example of France, Jones Day, Internal Publication (Oct. 2009), http://www.jonesday.com/ files/Publication/ff7fd833-8640-443c-bb46d6e756864345/Presentation/Publication Attachment/6e60f00f-0d2a-4c0c-b986-d7982522c1f6/Class\%20Actions\%202009.pdf. 
to enforcement of its securities laws. It may even open the way for competition between jurisdictions for private regulatory claims. ${ }^{192}$

In sum, as private enforcement catches on, and regulators around the world recognize the need for greater cooperation and improved enforcement of securities antifraud rules, the time is ripe for governments and other interested parties to begin work on a multilateral negotiated solution to the problems presented by transnational securities fraud. In the meantime, U.S. courts should be careful to preserve a flexible approach to the question of the extraterritorial application of U.S. antifraud rules, while still screening out claims by foreign plaintiffs that are not based on sufficient conduct within the United States. More aggressive use of discretionary dismissals on the base of international comity or forum non conveniens may be useful in this regard. ${ }^{193}$

${ }^{192}$ Buxbaum, Competition, supra note 9, at 7-8.

${ }^{193}$ Cf. Buxbaum, supra note 2, at 64-65. 